\title{
Head and Neck Cancer Pathologic Regional Lymph Nodes TNM Finding v8
}

National Cancer Institute

\section{Source}

National Cancer Institute. Head and Neck Cancer Pathologic Regional Lymph Nodes

TNM Finding v8. NCI Thesaurus. Code C132643.

A pathologic finding about one or more characteristics of head and neck cancer, following the rules of the TNM AJCC v8 classification system as they pertain to staging of regional lymph nodes. 